\title{
Pengaruh Minat Terhadap Hasil Belajar Geografi Dengan Model Inkuiri Terbimbing di SMAN 3 Samarinda
}

\author{
Yeftha $^{1}$, Zeni Haryanto ${ }^{2}$, Yulian Widya Saputra ${ }^{3^{*}}$ \\ 1,2,3 Prodi Pendidikan Geografi Universitas Mulawarman \\ *e-mail : bukit_12@yahoo.co.id
}

\begin{abstract}
Abstrak
Pembelajaran dengan pembimbingan guru mampu menarik minat serta meluruskan konsep saat siswa menyimpulkan hasil penyelidikannya. Penelitian ini bertujuan untuk mengetahui pengaruh minat terhadap hasil belajar geografi siswa kelas X MIPA 5 SMA Negeri 3 Samarinda. Jenis penelitian yang digunakan adalah kuantitatif yang bersifat sebab-akibat dimana variabel independen minat belajar siswa dan dependen yaitu hasil belajar siswa. Penelitian ini dibantu dengan variabel antara yakni model inkuiri terbimbing. Penarikan sampel secara purposive sampling dari keseluruhan populasi kelas $\mathrm{X}$ didapatkan jumlah sampel yakni 31 siswa. Pengumpulan data dalam penelitian ini lakukan dengan menggunakan dua cara yaitu, angket untuk mengetahui minat siswa serta soal post test untuk mengetahui hasil belajar siswa. Hasil penelitian ini menunjukkan nilai rata-rata hasil belajar siswa yaitu dengan nilai sebesar 76.00. Sedangkan perolehan ratarata nilai minat siswa sebesar 75.54. Adapun koefisisen korelasi yang diperoleh sebesar 0.048 yang artinya menunjukkan eratnya hubungan antara $X$ (minat) dan $Y$ (hasil belajar) dan besarnya koefisien determinan yang diberikan oleh $X$ terhadap $\mathrm{Y}$ adalah $12.8 \%$. Maka dapat diketahui nilai $t_{\text {hitung }}=2.066$ dengan nilai sig sebesar $0.048<0.05$ maka $\mathrm{H}_{\mathrm{a}}$ diterima dan $\mathrm{H}_{0}$ ditolak, yang berarti ada pengaruh antara variabel minat $(\mathrm{X})$ terhadap variabel hasil belajar siswa $(\mathrm{Y})$.
\end{abstract}

Kata kunci : minat, hasil belajar geografi, inkuiri terbimbing

\section{Influence of Interest Against Geography Learning Outcomes With the Guided Inquiry Model at SMAN 3 Samarinda}

\author{
Yeftha $^{1}$, Zeni Haryanto ${ }^{2}$, Yulian Widya Saputra ${ }^{3^{*}}$ \\ 1,2,3 Geography Education Department of Mulawarman University \\ *e-mail : bukit_12@yahoo.co.id
}

\begin{abstract}
Learning by mentoring the teacher is able to attract interest and straighten the concept when students conclude the results of their investigation. This study aims to determine the effect of interest in the learning outcomes of students of class $X$ MIPA 5 in SMA Negeri 3 Samarinda. This type of research is quantitative that is cause and effect where the independent variables student interest and dependent learning is student learning outcomes. This research is assisted with intermediate


variables namely guided inquiry models. Sampling by purposive sampling from the whole population of class $X$ obtained a sample of 31 students. Data collection in this study was conducted using two ways, namely, a questionnaire to determine student interests and post test questions to determine student learning outcomes. The results of this study indicate the average value of student learning outcomes with a value of 76.00. While the average acquisition value of student interest is 75.54. The correlation coefficient obtained by 0.048 which means that shows the close relationship between $X$ (interest) and $Y$ (learning outcomes) and the magnitude of the determinant coefficient given by $X$ to $Y$ is $12.8 \%$. Then it can be seen that the $t_{\text {count }}=2.066$ with a sig value of $0.048<0.05$ then $H_{a}$ is accepted and $H_{0}$ is rejected, which means there is an influence between the variable of interest $(X)$ on the variable of student learning outcomes $(Y)$.

Keywords: interests, geography learning outcomes, guided inquiry

\section{Pendahuluan}

Siswa yang berhasil dalam proses pembelajaran dipengaruhi oleh berbagai faktor. Berbagai faktor tersebut salah satunya berasal dari aspek psikologis. Faktor psikologis meliputi minat, motivasi, respon, aktivitas dan kematangan yang berbedabeda. Faktor psikologis ini bermakna bahwa tujuan pembelajaran diukur keberhasilannya dari bagaimana proses yang dialami siswa sebagai subjek pembelajaran di kelas.

Faktor dari psikologi yang diteliti adalah aspek minat siswa dalam pembelajaran. Minat belajar siswa dalam proses belajar perlu ditingkatkan agar memperoleh hasil yang belajar yang baik. Adanya kegiatan yang menarik dalam belajar akan meningkatkan minat belajar siswa di kelas.

Lebih lanjut dalam proses pembelajaran tidak hanya bersifat mentransfer pengetahuan saja, tetapi juga mampu menciptakan proses belajar yang menarik agar siswa berminat mengikuti pelajaran. Hal tersebut dapat dibantu melalui pemilihan model pembelajaran, sehingga dari pemilihan model pembelajaran tersebut tidak hanya guru yang berperan aktif dalam kelas melainkan siswa juga dapat berperan langsung dalam proses pemahaman materi.

Saat ini banyak dikembangkan berbagai macam model pembelajaran, dari semua model yang telah di kembangkan untuk keberhasilan dalam proses pembelajaran siswa. Kemudian bagaimana sebuah model dapat berpengaruh pada 
proses pembelajaran bahkan pada hasil belajar, tentu model tersebut harus bersifat membimbing.

Berdasarkan hasil wawancara serta observasi menunjukan bahwa ada beberapa masalah yang dialami oleh siswa selama proses pembelajaran berlangsung. Berbagai masalah tersebut dirangkum yakni siswa cenderung tidak berminat belajar geografi, siswa tidak terlalu aktif dalam belajar, dan nilai hasil belajar yang rendah dimana tidak mencapai nilai $K K M$ sekolah $\geq 75$. Oleh karena itu diidentifikasi bahwa faktor minat siswa yang kurang pada pelajaran geografi sehingga mempengaruhi hasil belajar siswa.

Berdasarkan paparan diatas dapat disimpulkan bahwa hasil belajar siswa juga dipengaruhi oleh faktor psikologis siswa yakni minat. Dengan demikian peneliti memilih judul penelitian dalam pembelajaran geografi materi hidrosfer dengan melihat pengaruh minat terhadap hasil belajar siswa menggunakan salah satu model yaitu inkuiri terbimbing (guided inquirr).

Berdasarkan latar belakang diatas, maka dapat dirumuskan permasalahan penelitian yakni bagaimana pengaruh minat terhadap hasil belajar siswa kelas $X$ di SMA Negeri 3 Samarinda dengan menggunakan model inkuiri terbimbing. Selanjutnya tujuan dari penelitian ini untuk mengetahui pengaruh minat siswa terhadap hasil belajar siswa kelas $\mathrm{X}$ di SMA Negeri 3 Samarinda dengan menggunakan model inkuiri terbimbing.

\section{Kajian Pustaka}

Lestari (2013) menyampaikan bahwa efektivitas pembelajaran melekat pada aktivitas belajar dan partisipasi siswa. Untuk dapat bersikap aktif dibutuhkan pula faktor penggerak yang secara langsung memberi dorongan pada siswa untuk bertindak. Faktor pendorong yang dimaksud adalah minat belajar. Selain itu Hurlock (1990:422) menambahkan bahwa minat merupakan hasil dari pengalaman atau proses belajar.Kedua pendapat Lestari dan Hurlock ini memfokuskan bahwa minat merupakan aktivitas, partisipasi juga kebebasan siswa yang diperoleh dari pengalaman untuk mendorong siswa untuk belajar. 
Lebih jauh Kambuaya (2015:160) menuliskan bahwa dalam minat memiliki dua aspek yaitu: (1) Aspek kognitif dimana konsep yang membangun aspek kognitif didasarkan atas pengalaman dan apa yang dipelajari dari lingkungan. (2) Aspek afektif, adalah konsep yang membangun konsep kognitif dan dinyatakan dalam sikap terhadap kegiatan atau objek. Tulisan dari Kambuaya ini mengandung makna bahwa siswa selama proses pembelajarannya tumbuh minat yang berawal dari pembangunan konsep kognitif terlebih dahulu. Selanjutnya tahapan berikutnya minat siswa muncul dalam bentuk perilaku (afektif) belajar di kelas.

Menurut Djamarah (2008:132) minat merupakan suatu kecenderungan yang menetap untuk memperhatikan dan mengenang beberapa aktivitas. Sedangkan Wibobo (2017) menyampaikan minat terdiri dari: (1) perhatian; (2) ketertarikan; (3) keingintahuan; (4) pilihan seseorang terhadap pembelajaran matematika. Slameto (2010:180) minat adalah suatu rasa lebih suka dan rasa keterkaitan pada suatu hal atau aktivitas, tanpa ada yang menyuruh. Berdasarkan ketiga pendapat diatas maka dapat disimpulkan bahwa minat adalah kesadaran seseorang terhadap suatu obyek atau sesuatu hal sehingga menimbulkan rasa senang dan tertarik. sedangkan Nana Sudjana (2009:3) mendefinisikan hasil belajar siswa pada hakikatnya adalah perubahan tingkah laku sebagai hasil belajar dalam pengertian yang lebih luas mencakup bidang kognitif, afektif, dan psikomotorik. Dimyati dan Mudjiono (2006:34) menyebutkan hasil belajar merupakan hasil dari suatu interaksi tindak belajar dan tindak mengajar.

Berdasarkan beberapa pendapat diatas maka dapat disimpulkan bahwa hasil belajar merupakan perubahan tingkah laku yang mencakup bidang kognitif, afektif, dan psikomotorik. Hasil belajar juga dapat diartikan sebagai keberhasilan yang telah dicapai oleh seseorang yang bisa diwujudkan dalam bentuk persentase angka.

Model pembelajaran adalah sebuah bentuk yang disusun menggunakan beberapa landasan atau prinsip tertentu. Beberapa landasan atau prinsip tersebut antara lain teori pengetahuan, teori psikologis, sosialis, analisis sistem dan teori-teori lain yang mendukung sebuah aktivitas pembelajaran. Berikut ini pengertian model pembelajaran menurut para ahli. Joyce dan Weil dalam Rusman (2014) dan Trianto (2010) yang mengartikan bahwa model pembelajaran adalah suatu perencanaan 
yang digunakan sebagai pedoman dalam merencanakan pembelajaran di kelas. Selanjutnya dari kedua pendapat ahli diatas dapat dimaknai pula bahwa perencanaan atau pola yang digunakan untuk membuat penjabaran kurikulum, silabus serta merancang materi pembelajaran.

Jauhar dalam Nurfausiah dan Suhardiman (2016) menyampaikan bahwa inkuiri terbimbing adalah adalah model pembelajaran dimana, guru membimbing siswa melakukan kegiatan dengan memberikan pertanyaan awal yang mengarahkan pada suatu diskusi. Guru memberikan peran aktif dalam menentukan permasalahan dan tahap permasalahan dan tahap pemecahan

Tahapan atau langkah dari model pembelajaran inkuiri terbimbing terdiri dari lima langkah. Menurut David dalam Sofiani (2011) Kelima langkah tersebut dapat dijelaskan sebagai berikut:

a. Orientasi

Orientasi mempersiapkan siswa untuk belajar, memberikan motivasi untuk berkreativitas, menciptakan minat pengetahuan sebelumnya. pengenalan terhadap tujuan pembelajaran dan kriteria keberhasilan memfokuskan siswa untuk menghadapi persoalan penting dan menentukan tingkat penguasaan yang diharapkan.

b. Eksplorasi

Siswa mempunyai kesempatan untuk mengadakan observasi, mendesain eksperimen, mengumpulkan, menguji dan menganalisa data, menyelidiki hubungan serta mengemukan pertanyaan dan menguji hipotesis.

c. Pembentukan konsep

Sebagai hasil eksplorasi, konsep ditemukan, dikenalkan dan dibentukkan. pemahaman konseptual dikembangkan oleh keterlibatan siswa dalam penemuan bukan penyampaian informasi melalui naskah atau ceramah.

d. Aplikasi

Aplikasi melibatkan penggunaan pengetahuan baru dalam latihan, masalah dan situasi penelitian lain. Latihan memberikan kesempatan kepada siswa untuk membentuk kepercayaan diri pada situasi yang sederhana dan konteks yang masuk ke dalam masalah-masalah nyata di dunia. 
e. Penutup

Setiap kegiatan diakhiri dengan membuat validasi terhadap hasil yang mereka dapatkan, refleksi terhadap apa yang telah mereka pelajari dan menilai penampilan mereka.

Kelima langkah tersebut secara sederhana dapat diamati pada gambar $1 \mathrm{di}$ bawah ini.

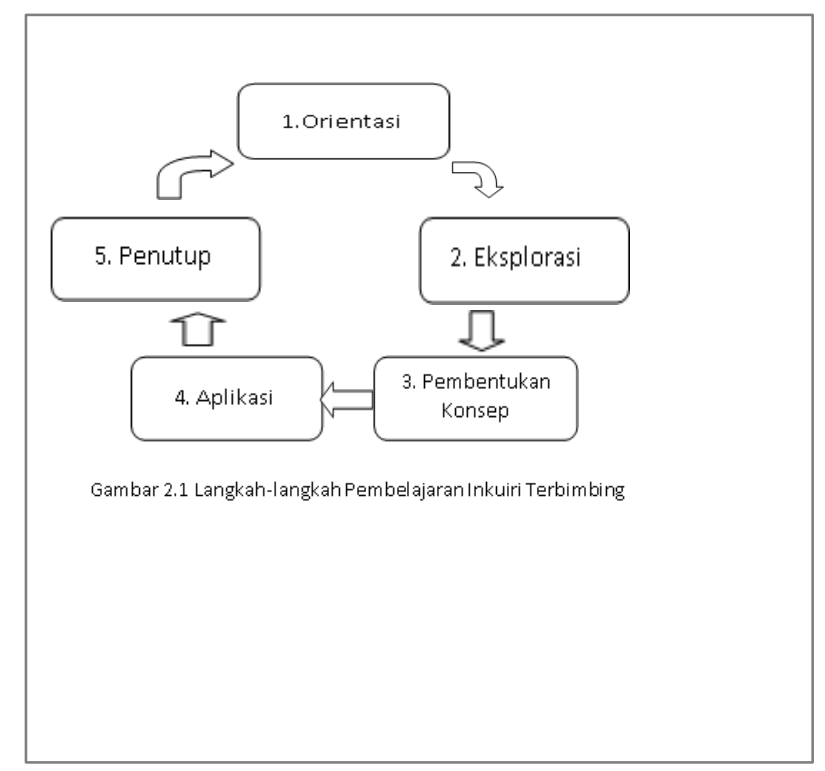

Gambar 1. Langkah Inkuiri Terbimbing

Berdasarkan beberapa penjelasan di atas maka dapar disimpulkan bahwa inkuiri terbimbing merupakan suatu model pembelajaran yang diawali dengan pengajuan masalah yang akan diselidiki oleh guru bersama siswa dan guru membimbing siswa melakukan penyelidikan hingga meluruskan konsep ketika siswa telah mampu menyimpulkan hasil penyelidikannya.

\section{Metode}

Jenis penelitian yang digunakan adalah penelitian kuantitatif. Populasi yang diambil pada penelitian adalah seluruh siswa kelas X SMA Negeri 3 Samarinda tahun ajaran 2016/2017 yang terdiri dari lima kelas. Sampel dalam penelitian ini diambil dengan teknik purposive sampling, artinya pengambilan sampel sebanyak satu kelas yaitu kelas X MIPA 5 dengan jumlah 31 siswa. Pemilihan sampel berdasarkan pertimbangan kemampuan siswa yang hampir sama. Teknik yang Pengaruh Minat Terhadap Hasil Belajar Geografi... Yeftha, Zeni Haryanto, Yulian Widya Saputra 
digunakan untuk mengumpulkan data penelitian jenis instrumen test yang digunakan yaitu post test yang diberikan sebanyak 15 soal dalam bentuk essay dan angket minat siswa terhadap pelajaran geografi yang terdiri dari 20 butir dan terbagi menjadi 10 pertanyaan positif dan 10 pertanyaan negatif.

\section{Hasil dan Pembahasan}

Berdasarkan temuan dalam penelitian, nilai minat siswa setelah diajarkan menggunakan model inkuiri terbimbing, yang masuk dalam kategori minat cukup baik sebesar $19 \%$ dan kategori baik dengan persentase $81 \%$, selain itu siswa yang masuk dalam kategori tidak baik, kurang baik, dan sangat baik sebesar $0 \%$ atau tidak ada yang masuk kategori ini. Perolehan persentase minat siswa mempengaruhi proses pembelajaran dan hasil belajar siswa. Kemudian hasil belajar siswa setelah diajarkan menggunakan model inkuiri terbimbing, terdapat sebesar 21 siswa dari 31 siswa. Frekuensi yang mencapai ketuntasan dan 10 siswa belum mencapai standar KKM geografi di SMA Negeri 3 Samarinda yaitu 75.

Dari data yang telah diperoleh, dan dilakukan analisis perhitungan hasil belajar dan minat siswa melalui bantuan aplikasi SPSS 16.0, maka didapatkan hasil regresi linear sederhana $Y=43.756+0.424 x$, yang berarti terdapat pengaruh minat terhadap hasil belajar siswa kelas X MIPA 5 SMA Negeri Samarinda, sebesar 12.8 $\%$ yang didapat dalam tabel model summary. Dan pada hasil output annova, menunjukan bahwa nilai signifikansi/robabilitas sebesar $0.048<0,05$. maka $\mathrm{H}_{\mathrm{a}}$ di terima dan Ho ditolah yang artinya bahwa minat berpengaruh terhadap hasil belajar siswa kelas X MIPA 5 SMA Negeri 3 Samarinda tahun ajaran 2016/2017.

Berdasarkan data angket minat belajar siswa diperoleh nilai standar deviasi sebesar 6.098 dan rata-rata 75.55 . nilai maksimal sebesar 87.00 dan nilai minimal sebesar 62.00. Tanggapan siswa terhadap pembelajaran geografi yang sudah dilangsungkan menggunakan model inkuiri terbimbing, terdapat sebesar 6 siswa atau $=19 \%$ dari total 31 siswa masuk dalam kategori minat cukup baik, kemudian terdapat sebesar 25 siswa atau $=81 \%$ dari total 31 siswa, terkategori dalam minat baik. hal ini menunjukan bahwa minat belajar siswa kelas X MIPA 5 setelah 
diajarkan menggunakan model inkuiri terbimbing, berpengaruh positif terhadap pelajaran geografi.

Namun demikian di sisi lain masih terdapat 6 siswa yang minatnya cukup baik, dipengaruhi oleh kesiapan belajar siswa, kesiapan belajar adalah salah satu penyebab meningkatnya minat belajar siswa karena seseorang tidak akan memiliki minat apabila mereka belum siap secara fisik maupun mental. Hal ini didukung oleh penelitian Mulyani (2013) yang menyampaikan bahwa siswa yang memiliki prestasi belajar matematika yang baik mempunyai minat dan kebiasaan belajar yang baik.

Kesiapan belajar siswa yang baik juga akan menghasilkan hasil belajar yang tinggi. Hal ini didukung oleh penelitian Umam dan Fakhruddin (2016) menyimpulkan bahwa dari hasil analisis data, kesiapan belajar peserta didik pada

program paket C PKBM Sunan Drajat berpengaruh sebesar $41 \%$ terhadap hasil belajar dimana skor $F$ hitung $=45,247$ lebih besar dari $F_{\text {tabel }}=3,99$, sehingga dapat ditarik kesimpulan bahwa $\mathrm{H}_{0}$ ditolak. Berdasarkan pada ditolaknya hipotesis nol $\left(\mathrm{H}_{0}\right)$ yang berarti bahwa diterimanya hipotesis kerja $(\mathrm{Ha})$ menunjukkan bahwa ada pengaruh kesiapan belajar terhadap hasil belajar peserta didik.

Kemudian minat juga dipengaruhi oleh rasa suka dari siswa selama pembelajaran berlangsung. Rasa suka akan timbul dalam diri siswa apabila ia bisa berpikir positif terhadap apa yang ia pelajari. Namun saat observasi selama penelitian rasa suka ini sedikit kurang muncul pada siswa di kelas X MIPA 5. Hal ini disebabkan beberapa dari siswa beranggapan bahwa pelajaran geografi itu masih bersifat hafalan. Hal ini didukung oleh penelitian dari Rozikin (2018) yang menyampaikan bahwa indikator pemahaman konsep materi indikator minat yang paling kecil pengaruhnya terhadap hasil belajar siswa adalah pada indikator perasaan suka terhadap aktivitas siswa dengan nilai rata-rata korelasi sebesar 0,274 .

Analisis dari hasil belajar siswa setelah diajarkan menggunakan model inkuiri terbimbing, diperoleh nilai rata-rata sebesar 76.00, untuk standar deviasi 7.214, dan nilai minimal yang didapat 60.00 , serta nilai maksimal 87.00 . Hasil belajar geografi dapat dipresentasikan dari 31 siswa, terdapat 10 siswa atau $=32 \%$ dengan kriteria 
cukup baik, 13 siswa atau $=42 \%$ dengan kriteria baik, kemudian 8 siswa atau $=26 \%$ dengan kriteria sangat baik.

Hasil data berupa persentase siswa ini menunjukan bahwa setelah diajarkan menggunakan model inkuiri terbimbing memiliki pengaruh positif terhadap hasil belajar siswa, dimana $68 \%$ siswa telah mencapai kriteria ketuntasan minimal (KKM), dan terdapat $32 \%$ siswa belum mencapai KKM. Artinya lebih dari $50 \%$ siswa telah berhasil mencapai tujuan pembelajaran dengan menggunakan model inkuiri terbimbing. Dan sebesar 32\% siswa masih belum mencapai nilai KKM. Hasil ini didukung oleh penelitian dari Antasari (2017:11) melalui model inkuiri terbimbing pemahaman konsep siswa mengalami peningkatan

Berdasarkan temuan yang telah dilakukan peneliti di kelas X MIPA 5 SMA Negeri 3 Samarinda, diidentifikasikan bahwa 10 siswa yang memperoleh nilai kurang dari KKM, dipengaruhi oleh faktor ekstern atau faktor yang berasal dari luar diri siswa. Hal ini didukung oleh penelitian dari Hal ini didukung oleh Nurhasanah dan Sobandi (2016) yang menyatakan bahwa melalui nilai koefisien determinasi dalam penelitian ini diperoleh $21,77 \%$. Arti dari nilai koefisien determinasi ini adalah bahwa hasil belajar dipengaruhi oleh minat belajar sebesar $21,77 \%$ sisanya $78,23 \%$ dipengaruhi oleh faktor-faktor lain yang tidak diteliti dalam penelitian ini.

Faktor-faktor tersebut dapat diidentifikasi berupa faktor eksternal dan internal. Kedua faktor ini selama penelitian memberikan $78,23 \%$ faktor lain yang tidak diteliti. Faktor internal secara umum diidentifikasi berkaitan erat dengan kondisi fisiologi dan psikologis siswa. Faktor eksternal diidentifikasi berasal dari lingkungan. Oleh karena itu kedua faktor ini diduga mempengaruhi 10 siswa yang memperoleh nilai di bawah KKM.

Lebih jauh faktor internal selama proses penelitian diidentifikasi berkaitan dengan kondisi fisiologis dan psikologis dari siswa. Selama proses penelitian didapatkan hasil observer menunjukkan faktor psikologis siswa seperti perhatian akan pelajaran geografi sedikit berkurang. Perhatian ini seperti pada awal pembahasan berkenaan dengan pandangan bahwa materi geografi cenderung menghapalkan. 
Faktor internal yang lain adalah fisiologis siswa seperti kondisi kesehatan dan kebugaran siswa dalam menerima pelajaran geografi. Namun selama penelitian tidak ditemui faktor internal seperti gangguan kesehatan atau kebugaran siswa. Secara umum jika selama penelitian ditemukan gangguan terhadap kondisi fisiologi siswa tentunya berdampak pada pembelajaran

Selain faktor perhatian, sisi psikologis siswa antara lain berkaitan pula dengan, bakat, motif, motivasi, kognitif dan daya nalar peserta didik. Hal ini didukung oleh Hapnita, dkk (2017) menyatakan bahwa faktor internal antara lain bakat, intelegensi, kondisi kesehatan dan lain-lain. Faktor eksternal merupakan faktor yang berasal dari lingkungan siswa. Faktor lingkungan ini meliputi lingkungan fisik dan lingkungan sosial. Lingkungan alam misalnya suhu, kelembaban dan lain-lain. Waktu belajar kelas yang berada pada tengah hari di ruangan yang kurang akan sirkulasi udara akan sangat berpengaruh pada kondisi kelas. Hal ini berbeda pada pembelajaran pada pagi hari yang kondisinya masih segar dan dengan ruangan yang cukup untuk udara bersirkulasi secara terus menerus. Hal ini didukung oleh Sawawa (2018) yang menyampaikan bahwa siswa yang mendapatkan nilai di bawah KKM ini disebabkan oleh beberapa faktor, diantaranya faktor eksternal, misalnya: guru, teman, keluarga, masyarakat, sarana. Secara parsial faktor kecerdasan intelektual, minat belajar dan kebiasaan belajar berpengaruh positif terhadap hasil belajar .

Kemudian faktor instrumental. Faktor instrumental adalah faktor yang keberadaan dan penggunaannya dirancang sesuai dengan hasil belajar yang diharapkan. Faktor-faktor ini diharapkan dapat berfungsi sebagai sarana untuk tercapainya tujuan-tujuan belajar yang direncanakan. Faktor-faktor instrumental ini berupa kurikulum, sarana dan guru. Hal ini senada dengan Pingge (2016) menyebutkan faktor instrumental berupa instrumen atau fasilitas pembelajaran baik yang berupa hardware maupun software serta lingkungan, baik lingkungan sosial maupun lingkungan alam. Berdasarkan pendapat Pingge tersebut diketahui bahwa faktor instrumental dapat pula digolongkan dalam faktor eksternal. Hal ini diklasifikasikan lain di luar eksternal agar penjelasan lebih terperinci. 
Sebagai tambahan akhir dalam pandangan teori belajar konstruktivisme menekankan bahwa pengetahuan siswa adalah konstruksi (bentukan) dari siswa itu sendiri. Makna pernyataan ini adalah proses belajar berpusat kepada siswa sebagai subjek belajar. Pengetahuan bukanlah suatu fakta yang tinggal ditemukan, melainkan suatu perumusan yang diciptakan oleh individu (siswa) yang sedang mempelajarinya. Upaya untuk meningkatkan hasil belajar siswa hendaknya juga didukung dengan mengoptimalkan peran semua faktor pendukung hasil belajar, baik faktor internal maupun faktor eksternal.

\section{Kesimpulan}

Berdasarkan analisis data dan pembahasan hasil penelitian maka dapat disimpulkan bahwa setelah diajar menggunakan model inkuiri terbimbing minat berpengaruh terhadap hasil belajar siswa kelas X MIPA 5 SMA Negeri 3 Samarinda, sebesar $12.8 \%$ sehingga masih tersisa $87.2 \%$ faktor lain yang juga dapat mempengaruhi hasil belajar. Bedasarkan temuan peneliti di kelas X MIPA 5 SMA Negeri 3 Samarinda, diduga bahwa 87.2\% faktor lain yang juga mempengaruhi hasil belajar adalah, faktor internal dan faktor eksternal yang dimiliki siswa.

Selanjutnya untuk penelitian lebih jauh diperlukan sinergi yang baik dimana sekolah harus mampu menciptakan suasana belajar yang dapat mengintegrasikan semua faktor yang mendukung keberhasilan belajar siswa. Langkah tersebut harus dilakukan secara sadar, simultan dan berkesinambungan.

\section{Daftar Pustaka}

Antasari, Novita. 2017. "Penerapan Model Inkuiri Terbimbing Untuk Meningkatkan Pemahaman Konsep IPA Siswa Kelas". Jurnal Pendidikan Guru Sekolah Dasar, 2 (3): 1-13.

Dimyati dan Mudjiono, 2006. Belajar dan Pembelajaran. Jakarta : PT. Rineka.

Djamarah, Syaiful Bahri, 2008. Psikologi belajar. Jakarta : PT. Rineka Cipta

Hapnita, Widia dkk. 2017. "Faktor Internal Dan Eksternal Yang Dominan Mempengaruhi Hasil Belajar Menggambar Dengan Perangkat Lunak Siswa Kelas Xi Teknik Gambar Bangunan Smk N 1 Padang Tahun 2016/2017". Jurnal CIVED 5 (1).

Hurlock, E.B. 1990. Psikologi Perkembangan Edisi 5. Jakarta: Erlangga.

Pengaruh Minat Terhadap Hasil Belajar Geografi...

Yeftha, Zeni Haryanto, Yulian Widya Saputra 
Kambuaya, Carlos. 2015. "Pengaruh Motivasi, Minat, Kedisiplinan, dan Adaptasi Diri Terhadap Prestasi Belajar Siswa Peserta Program Afirmasi Pendidikan Menengah Asal Papua dan Papua Barat di Kota Bandung". Social Work Jurnal 5 (2) : 106-208.

Lestari, Indah . 2013. Pengaruh Waktu Belajar dan Minat Belajar terhadap Hasil Belajar Matematika. Jurnal Formatif 3(2): 115-125.

Mulyani, Dessy. 2013. "Pengaruh Minat Dan Kebiasaan Belajar Siswa Terhadap Prestasi Belajar Matematika". Jurnal Formatif 2(2): 122-131.

Nurfausiah dan Suhardiman. 2016. "Pengaruh Model Pembelajaran Inkuiri Terbimbing Terhadap Hasil Belajar". Jurnal Pendidikan Fisika 4 (1).

Nurhasanah, S dan Sobandi, A. 2016. "Minat Belajar Sebagai Determinan Hasil Belajar Siswa". Jurnal Pendidikan Manajemen Perkantoran. 1 (1): , 128-135.

Pingge, HD Dkk. 2016. "Faktor Yang Mempengaruhi Hasil Belajar Siswa Sekolah Dasar Di Kecamatan Kota Tambolaka". JPSD : Jurnal Pendidikan Sekolah Dasar 2 (1)

Rozikin, Slamet dkk. 2018."Hubungan Minat Belajar Siswa Dengan Prestasi Belajar Siswa Pada Mata Pelajaran Kimia Di Sma Negeri 1 Tebat Karai Dan Sma Negeri 1 Kabupaten Kepahiang". Alotrop. Jurnal Pendidikan dan IImu Kimia, 2018:2(1):78-81.

Rusman. 2010. Model-Model Pembelajaran: Mengembangkan Profesionalisme Guru. Jakarta: PT Raja Grafindo Persada

Sawawa, Danur dkk, 2018. "Pengaruh Faktor Internal Dan Eksternal Siswa Terhadap Hasil Belajar Pada Mata Pelajaran Mekanika Teknik Dan Elemen Mesin". Journal of Mechanical Engineering Education, 5 (1).

Slameto. 2010. Belajar dan faktor-faktor yang mempengaruhinya. Jakarta : PT. Rineka

Sofiani, Erlina. 2011. Pengaruh Model Inkuiri Terbimbing (Guided Inquiry) Terhadap hasil Belajar Fisika Siswa Pada Konsep Listrik Dinamis.

Sudjana, Nana, 2009. Penilaian Hasil Proses Belajar Mengajar. Bandung : PT. Remaja Rosdikarya

Trianto, 2010. Model Pembelajaran Terpadu. Jakarta: Penerbit : Bumi Aksara

Umam, K A dan Fakhruddin. 2016. "Pengaruh kesiapan Belajar Terhadap Hasil Belajar Peserta Didik Program Paket C". Journal of Nonformal Education. 
